IRA-International Journal of Management \& Social Sciences

ISSN 2455-2267; Vol.08, Issue 01 (July 2017)

Pg. no. 124-134

Institute of Research Advances

http://research-advances.org/index.php/RAJMSS

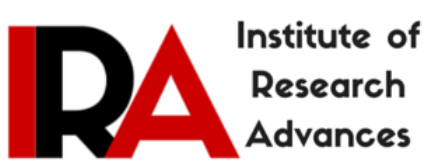

\title{
Effect of Communication, Governance and Financial Capability on Service Quality and Lecturer Performance
}

\author{
Syahrir DM ${ }^{1}$, Murdifin Haming ${ }^{2}$, Zainuddin Rahman ${ }^{3}$, Junaiddin Zakaria ${ }^{4}$ \\ ${ }^{\mathbf{1}}$ Doctoral Student in the Faculty of Economics, Muslim University of Indonesia, Indonesia. \\ 2,3,4 Faculty of Economics, Muslim University of Indonesia, Indonesia.
}

Type of Review: Peer Reviewed.

DOI: http://dx.doi.org/10.21013/jmss.v8.n1.p14

\section{How to cite this paper:}

DM, Syahrir, Haming, M., Rahman, Z., \& Zakaria, J. (2017). Effect of Communication, Governance and Financial Capability on Service Quality and Lecturer Performance. IRA-International Journal of Management \& Social Sciences (ISSN 2455-2267), 8(1), 124-134. doi:http://dx.doi.org/10.21013/jmss.v8.n1.p14

(C) Institute of Research Advances.

\section{(cc) BY-NC}

This work is licensed under a Creative Commons Attribution-Non Commercial 4.0 International License subject to proper citation to the publication source of the work.

Disclaimer: The scholarly papers as reviewed and published by the Institute of Research Advances (IRA) are the views and opinions of their respective authors and are not the views or opinions of the IRA. The IRA disclaims of any harm or loss caused due to the published content to any party.

Institute of Research Advances is an institutional publisher member of Publishers Inter Linking Association Inc. (PILA-CrossRef), USA. The institute is an institutional signatory to the Budapest Open Access Initiative, Hungary advocating the open access of scientific and scholarly knowledge. The Institute is a registered content provider under Open Access Initiative Protocol for Metadata Harvesting (OAI-PMH).

The journal is indexed \& included in WorldCat Discovery Service (USA), CrossRef Metadata Search (USA), WorldCat (USA), OCLC (USA), Open J-Gate (India), EZB (Germany) Scilit (Switzerland), Airiti (China), Bielefeld Academic Search Engine (BASE) of Bielefeld University, Germany, PKP Index of Simon Fraser University, Canada. 


\begin{abstract}
The purpose of this study was to analyze the effect of communication, governance and financial capacity on service quality and lecturer performance. The population in this study is 2,381 lecturers in Makassar area, slovin formulation was used to obtain 342 lecturers as a sample. Data from the questionnaires were analyzed using Structural Equation Model using AMOS Ver. 18. The study found that the communication and governance positive and significant effect on service quality, financial capability has a negative and no significant effect on service quality. Communication and financial capability has a positive and significant effect on lecturers performance, while the governance positive and insignificant effect on lecturers performance. Service quality has a positive and significant effect on lecturers' performance. Indirectly for variable i.e. service quality as a mediating role has a positive and insignificant in explaining the effect of communication on lecturer performance, Service quality as a mediating role has a positive and insignificant in explaining the effect of governance on lecturer performance. On the other section, service quality as a mediating role has a negative and significant in explaining the effect of financial capabilities on lecturer's performance.
\end{abstract}

Keywords: Communication, governance, financial capabilities, service quality, lecturer performance

\title{
Introduction
}

Understanding the background of this research cannot be separated from Act No. 20 of 2003 on Indonesian Education System, which provides confirmation that the private colleges and universities there should be no dichotomy, where both public and private universities alike. Based on the foundation of the law, Private Universities (PTS) with funding provided by the community, while the State Universities (PTN) funding from government sources. However, in its application show that the same presence in implementing the national education system.

A private university in the decades of ten years indicates there are three conditions. There are colleges that are progressing rapidly, there are stagnating and some are experiencing closures of courses, transformation and transfer of governance. This condition is different from each college. Advanced college does not become a problem, but for college stagnant and closed of course be a problem due to non-fulfilment of the requirements as a college representative in the process of implementation and management of education. Problems faced by the PTS is still low independence of universities facing the dynamics of increasingly fierce competition among universities, colleges, polytechnics and colleges (Djokopranoto, 2009: 74).

The development of the private college lecturer in the scope Kopertis Region IX in Makassar there are 4,511 lecturers, with details for private universities there are 19, with the number of lecturers 2824 and there are 59 private high schools with 1,687 the number of lecturers. This organizes the lecture. A Private university will be existing among the re-accreditation process. This refers to meet the demands of Higher Education Act No. 20 of 2003 which requires that all majors' courses (study program) universities should qualify accreditation as specified BAN-PT. Similarly, faculty lecturer qualification requires a minimum level of education has a master program.

Universities need to improve itself to improve the lecturers performance with private universities improve service quality; improve communication effectiveness, improved governance and financial capacity of the college. The precondition the provision of education should be able to create autonomous university autonomy in accordance with the achievement of faculty performance in delivering superior quality educational services (Charvert, 2010: 36). This corresponds to the theory of educational success, that educational success is determined by effective communication, organizational management, financial management capability and quality of service appropriate human resource performance achievement (Mills, 2004: 122).

Phenomenon found in several universities in the South Sulawesi province, especially college located in Makassar, in fact, the performance of the lecturer is still low in some private universities. This can be judged from some lecturers were not able to actualize the well of three pillars of higher education. Indeed of three pillars of higher education and the other supporting a faculty performance rating. Measuring the performance of the lecturer is reflected in the implementation of the three pillars of higher education and other support (Sumego, 2008: 75). 
A university in Makassar currently numbering 78 private university by the number of faculty employed as a lecturer is still shows the performance is still low. Faculty performance on private university in Makassar still needs to be improved, particularly improved performance in education-related activities of the learning process (lectures), an increase in research activities (personal, collective and institutional), and increased community service is best done through mentoring community work, mentoring practice in community and professional dedication.

According to the provisions of the Director General of Higher Education Ministry for Research, Technology and Higher Education provide an assessment of the three responsibilities of public and private universities to be achieved weight as a standard assessment for: a) education and learning by $35 \%$; b) the study by $45 \%$; c) $10 \%$ of public service; and d) supporting of three pillars of higher education (Tridharma) activities of 10\% (Higher Education, 2015, www.dikti.go.id).

The reality of private universities in Kopertis Region IX in Makassar has not demonstrated the achievement of faculty performance that corresponds to the expected target of the number of active lecturer amounted to 4,511 people in Makassar. Table 1 shows the performance of lecturers in Kopertis Region IX of Makassar in particular, the views of the weight of the performance assessment of lecturers from the aspect of education and learning in the last five years has decreased from $33.9 \%$ in 2011 amounted to $31.5 \%$ in 2015 with a teaching load sparse which met from lecturers to take courses 9 credits, for the field of research also did not reach the standard set is only equal to $40.9 \%$ in the year 2011 amounted to $35.4 \%$ in 2015 , in which the ability of faculty to conduct research and scientific papers are not met for be published at least three research every year. Aspects of community service looks only reached $8.5 \%$ in 2011 and decreased to $6.3 \%$ in 2015, this means the actualization of community service performed by lecturers declined in various forms of learning activities and other activities are performed, and to support the three pillars of higher education activities (Tridharma) in 2011 achieved $7.2 \%$ decline to 5.5\% in 2015 which means that the lecturers are rarely involved in various activities of regional and international forums. More details can be shown weight rating lecturer performance of private university (PTS) based on three pillars of higher education and supporting as follows:

Table 1. Performance assessment score of Lecturer at private universities is based on three pillars of higher education (Tridharma) and the other supporting performance activities on Kopertis Region IX Sulawesi

\begin{tabular}{|c|c|c|c|c|}
\hline Years & $\begin{array}{c}\text { Education and } \\
\text { Learning (\%) }\end{array}$ & Research (\%) & $\begin{array}{c}\text { Community Service } \\
(\%)\end{array}$ & $\begin{array}{c}\text { Other supporting } \\
\text { performance Activities (\%) }\end{array}$ \\
\hline 2011 & 33.9 & 40.9 & 8.5 & 7.2 \\
\hline 2012 & 32.4 & 40.3 & 8.2 & 6.9 \\
\hline 2013 & 32.2 & 39.5 & 7.5 & 6.2 \\
\hline 2014 & 31.8 & 37.6 & 6.9 & 5.9 \\
\hline 2015 & 31.5 & 35.4 & 6.3 & 5.5 \\
\hline
\end{tabular}

Source: Kopertis Region IX Sulawesi (2016)

The table shows the phenomenon of performance of lecturers, into the spotlight for the Kopertis Region IX Sulawesi to private colleges in the City Makassar to improve its performance through the development of the three pillars of higher education (Tridharma) College. On that basis, it is necessary to apply the theory of outcomes of work, that the performance of the lecturer is an assessment of the work in accordance with the fields of education, research and service (Rogers, 2007: 6). That is, the application of the theory of this work is correlated with the implementation of the three pillars of higher education (Tridharma) in higher education should be run optimally.

Achievement of optimal performance of lecturers who have not occurred in several private universities in Makassar, this is directly affected by the quality of services provided by the universities where professors placed. Often found lecturers complain about the quality of services provided by private universities, especially with regard to the quality of the interaction, the quality of the physical environment and the quality of the results. The services quality provided of private universities to the faculty led to lower performance due to the lack of effective and productive interaction between the Foundation as manager of private universities with professors, between each faculty, and between faculty and students. The quality of this interaction is often strained, leading to acceptance of service perceived by less qualified lecturers that affect performance. The low of services quality level available physical environment with regard to the means of lectures, tools and supplies that support the lectures and the limited access 
that support lecturers to improve its performance. Including college professors perceived outcome is still lacking, particularly with regard to the achievement of performance, acceptance of low incentives and do not get an award or a promotion.

As a result of the quality of services at private universities is still low which affects the performance of lecturers. On that basis it is necessary to consider the theory of quality of service, that service quality determines one's work. Increasing the work can be interpreted as an assessment of the achievement of performance (Brady and Cronin, 2008: 19). Responding relation to the performance of service quality faculty, it is relevant to some previous studies, among others, the findings of previous research showed a positive and significant effect on the quality of service on the performance of lecturers (Wulandari, 2010). There is a positive and significant influence between the qualities of service to employee's performance of Islamic banking (sharia) (Sumantri, 2011). Services quality is a significant negative effect on the performance of the employee (Sebastian Andrew, 2012); services quality is positive and significant impact on lecturer's performance (Jonathan, 2010).

The effectiveness of communication does not run as expected because there was a communication error. Communication of poor quality that often occur in several universities due to resources that are not clear, the message is less constructive, are not proper communication channels and people earning less understand, resulting in frequent communication error occurs. As a result of lack of communication viewed from the source, message, channel and receiver, causing services quality provided by the private universities less to the faculty lecturer because decreased performance in the process of development of education, research and service. Because it is necessary to consider the theory of communication, that the communication is determined by the input, process and output communication based on source, message, channel and receiver between information providers and recipients of information (DeVito, 2008: 48).

Understanding the importance of communication on the implementation and improvement of service quality faculty performance, then there is some previous researchers provide evidence that the effectiveness of communication as exogenous variables positive and significant impact on the quality of service and performance of lecturers (Wulandari, 2010). Communication variables had a negative impact and no significant effect on the quality of service and employee performance (Sumantri, 2011), there are positive influence and insignificant in communication, either directly or indirectly to the service quality and employee performance (Luqman Nugraha, 2010).

Another phenomenon affecting the low quality of private universities and the level of attainment of faculty performance cannot be separated from the role of the governance of a university. Governance question is for workers in the private universities that administer various college activities in serving the faculty and students. In fact, governance is applied in service at several universities in the inability to perform college governance in a credible, transparent, accountable, responsible and fair.

Governance capabilities in the management of the college is expected to provide good quality services in support of faculty performance, but the reality of governance in the service of a lack of trust in carrying out work activities properly, less transparent in expressing the problems of work, lack of accountability in making accountability work report, less responsible for the mandate given and tend to be discriminatory that cause no justice in service to the faculty. This fact is there should be a reform of governance in managing the private universities oriented service quality improvement and enhancement of faculty performance by applying the theory paradigm that every policy decision in the improvement and good governance should be taken paradigm right decision. Paradigm decisions nice working procedures include the management of a credible, transparent, accountable (accountable), responsible and fair. This decision is important paradigm theory to apply to private universities (Simmons, 2010: 49).

Addressing the importance of applying appropriate governance paradigm decisions good governance, then there are some researchers previously used as a reference for understanding the relationship of governance with the quality of service and improved performance, as in empirical results which provide evidence that governance has a negative impact and does not significantly to the service quality and improved performance (Thahir Gunawan, 2011). Governance has a positive and significant on service quality and performance (Jamal Karim, 2011). Both of effect has shown that the governance have a negative and insignificant effect on service quality and performance (Muller, 2011). 
The next problem related to the decrease in the quality of service of private universities and faculty performance is inseparable from the aspect of financial capability. It is recognized that the management of a private university financial management capability is very important, because the survival of a college is highly dependent on the financial management of public resources that students who pay the semester credit system (SKS) each semester, the development contribution expenses and other payments. Therefore the financial capability should be considered properly. In fact in some private universities, financial capability is still low in terms of reporting activities related to the use of budget activities, reporting financial budget itself and financing expense reporting academic use. As a result of the still low financial capability of the private universities cause decreased service quality and the achievement of faculty performance decreases as well. On this basis it is necessary to apply the independent financial theory makes clear that the organization's financial capability should be independent and responsible and appropriate activity budgets activity reporting, budget management and financing of the budget (Waltond, 2010: 78).

Based on the importance of applying financial capabilities, then there are some researchers previously used as a reference for understanding the relationship with the financial capability of service quality and increased performance provided evidence that the financial capabilities that provide a significant and positive effect on the quality of service and performance improvements? Variables examined focusing on the observation lecturers at private universities with the status of civil servants (conjunct) and lecturer in private universities with the status of employees of the foundation (Wulandari, 2010). Financial capability has a positive and insignificant effect on service quality and performance (Sebastian Andrew, 2012). Another study provides evidence that directly or indirectly, financial capability and significant positive effect on the quality of service and performance (Solomon Adams, 2011). Financial capabilities have a negative and insignificant effect on service quality and performance, the research focuses on the observation of Islamic banking employees (Sumantri, 2011).

After understanding the above description, it is important to do research, because this research has differences with previous research, especially with regard to the variables and indicators were observed. Besides other reasons researchers based on data obtained show that the performance of professors has decreased, so researchers consider important researching it seen from the influence of communication effectiveness, governance, financial capability and quality of service that apply to private colleges.

\section{Literature review and hypothesis development}

\section{Communication}

Communication was observed in this study refers to the communication theory by DeVito (2008: 48) states that the communication is determined by the input, process and output communication based on source, message, channel and receiver between information providers and information receivers.

$\mathrm{H}_{1} \quad$ Communication has a positive and significant effect on service quality.

$\mathrm{H}_{4} \quad$ Communication has a positive and significant effect on lecturer's performance.

$\mathrm{H}_{8} \quad$ Service quality as a mediating role in explaining the communications has a positive and significant effect on lecturers performance.

\section{Governance}

Governance paradigm using the decision theory (Simon, 2010: 49) that each policy in the improvement and good governance should be taken paradigm right decision. Paradigm decisions nice working procedures include the management of a credible, transparent, accountable, responsible and fair.

$\mathrm{H}_{2} \quad$ Governance is positive and significant effect on service quality.

$\mathrm{H}_{5} \quad$ Governance is positive and significant effect on lecturer's performance.

$\mathrm{H}_{9} \quad$ Service quality as a mediating role in explaining the governance has a positive and significant effect on lecturers performance

\section{Financial capability}

Financial capability used that refers to the theories of financial independence (independent financial theory) proposed Walton (2010: 78), that the organization's financial capacity to be independent and responsible and appropriate activity of financial activity reporting, financial management and financial funding.

$\mathrm{H}_{3} \quad$ Financial capability has a positive and significant effect on service quality.

$\mathrm{H}_{6} \quad$ Financial capability has a positive and significant effect on lecturer's performance. 
$\mathrm{H}_{10} \quad$ Service quality as a mediating role in explaining the financial capability has a positive and significant effect on lecturers performance

\section{Service quality}

Service quality on private universities refers to the quality of the service proposed theory, that the quality of service determines a person's work. The services quality has needs to be fixed to any person that is creating interaction quality and physical environment to improve their work (Brady and Cronin, 2008: 19).

\section{Lecturer performance}

Lecturer performance refers to the theory of the work (outcomes of work), that the performance of the lecturer is an assessment of the work in accordance with the fields of education, research and service (Rogers, 2007: 6).

$\mathrm{H}_{7} \quad$ Service quality has a positive and significant effect on lecturer's performance.

\section{Methods}

This study was designed to address problems that have been formulated and the goals to be achieved and to test the hypothesis. The type of data in this study consisted of primary and secondary data. Primary data is data obtained from the results of questionnaires and interviews. Secondary data is data obtained from Kopertis Region IX Sulawesi. The population in this study are all professors of Private Universities and Colleges listed in Kopertis Region IX in Makassar. Determination of the study population is purposively based on the number of lecturers. For universities who have chosen regular lecturers of $>200$ and regular lecturers of $>100$ for high schools, that the totalling 2,381 lecturers. The sample in this study was 342 respondents. Data analysis techniques used in explaining the phenomenon in this research is descriptive statistical analysis techniques and analysis of Structural Equation Modeling (SEM).

\section{Analysis and Discussion}

Based on the method of determining the value of the model, the first model testing variables are grouped into exogenous variables and endogenous variables. Exogenous variables are a variable whose value is determined outside the model. While the endogenous variable is a variable whose value is determined by an equation or model relationship is formed. Included in this group of exogenous variables is the measurement of communication, governance and financial capabilities, while classified as an endogenous variable is the quality of service and lecturers performance. The results of the model test is based on test goodness of fit indices in the table below to indicate the model criteria as well as the critical value is shown as follows:

Table 2. Goodness of Fit Indices Overall Model

\begin{tabular}{|c|c|c|c|c|c|}
\hline $\begin{array}{c}\text { Goodness of } \\
\text { fit index }\end{array}$ & Cut-off Value & $\begin{array}{c}\text { Model results } \\
\text { Preliminary }\end{array}$ & annotation & $\begin{array}{c}\text { Model results } \\
\text { Final Stage }\end{array}$ & annotation \\
\hline Chi-square & Expected of smaller & 1584.294 & Marginal & 467397 & Good \\
\hline Probability & $\geq 0: 05$ & 0,000 & Marginal & 0,092 & Good \\
\hline CMIN / DF & $\leq 2: 00$ & 3,064 & Marginal & 1,092 & Good \\
\hline RMSEA & $\leq 0: 08$ & 0,078 & Marginal & 0,016 & Good \\
\hline GFI & $\geq 0.90$ & 0,762 & Marginal & 0,926 & Good \\
\hline AGFI & $\geq 0.90$ & 0,726 & Marginal & 0,897 & Marginal \\
\hline TLI & $\geq 0.94$ & 0,723 & Marginal & 0,988 & good \\
\hline CFI & $\geq 0.94$ & 0,745 & Marginal & 0,991 & good \\
\hline df & & 517 & & 428 & \\
\hline
\end{tabular}

The results of the evaluation model for early stage shows of the eight criteria of goodness of fit indices everything will yet eligible cut-off value, which be modified model fits with hints of modification indices, as previously 
described. After the modification of the model, then the final stages showed no indicator variable seven criteria of goodness of fit indices have met the criteria or match the criteria of $a$ cut-off value, so that the model can be said to have been in accordance with the criteria of goodness of fit indices for analysis.

Table 3. Hypothesis Testing

\begin{tabular}{|l|c|c|c|c|c|c|c|}
\hline \multicolumn{1}{|c|}{ Exogenous } & Intervening & Endogenous & $\begin{array}{c}\text { P- } \\
\text { Value }\end{array}$ & $\begin{array}{c}\text { Direct } \\
\text { Effect }\end{array}$ & $\begin{array}{c}\text { Indirect } \\
\text { Effect }\end{array}$ & $\begin{array}{c}\text { Total } \\
\text { Effect }\end{array}$ & Annotation. \\
\hline Communications & - & Service quality & 0,042 & 0.682 & - & 0.682 & Significant \\
\hline Governance & - & Service quality & 0,014 & 0.739 & - & 0.739 & Significant \\
\hline Financial capability & - & Service quality & 0,288 & -0.636 & - & -0.636 & Insignificant \\
\hline Communications & - & Lecturer performance & 0,044 & 0.274 & - & 0.274 & Significant \\
\hline Governance & - & Lecturer performance & 0,935 & 0.011 & - & 0.011 & Insignificant \\
\hline Financial capability & - & Lecturer performance & 0,048 & 0.452 & - & 0.452 & Significant \\
\hline Service quality & & Lecturer performance & 0,032 & 0.293 & - & 0.293 & Significant \\
\hline Communication & Service quality & Lecturer performance & 0,139 & 0.279 & 0.200 & 0.474 & Insignificant \\
\hline Governance & Service quality & Lecturer performance & 0,104 & 0.009 & 0.216 & 0.228 & Insignificant \\
\hline Financial capability & Service quality & Lecturer performance & 0,340 & 0.356 & -0.186 & 0.266 & Insignificant \\
\hline
\end{tabular}

Overall hypothesis test results in Table 3 shows, there are five hypotheses serving positive and significant direct effect, that the first hypothesis, Secondly, fourth, sixth and seventh. Other five were insignificant (hypothetical third, fifth, eighth, ninth and tenth). One of them is negative and insignificant. One lane direct positive influence and insignificant, one lane indirect influence is positive and significant, one lane indirect positive effect and insignificant, as well as an indirect effect track negative and significant.

The interpretation of Table 3 can be explained as follows:

Communication has a positive and significant effect on services quality amounted of 0,832 (p-value $=0,042$, < 0.05). According to Table 3 , the dominant contribution of communication indicator is an indicator of the sixth with a loading factor of 0,663 and the smallest contribution indicator is eighth (loading factor $=0,448$ ). The sixth indicator is the effect or an outcome, which is the level of understanding of students to instructional materials delivered lecturers on teaching and learning (learn how to teach). Indicators eighth is noise (interference), is everything that affects the lack of effective transfer of information (teaching materials) from faculty to students. This means, a lecturer in a lecture delivered material particular emphasis on student understanding on lectures delivered. Lecturer, less attention to aspects of interference (noise) which will affect students' understanding of the material presented. Pressure on the results of communication that triggered this variable to be positive and significant influence on service quality (especially lectures). This is supported by research Wulandari (2010), which showed the communication a positive and significant effect on service quality.

Governance has a positive and significant effect on service quality of 0,711 ( $\mathrm{p}$-value $=0,014$ ). The indicator is an indicator of the dominant contribution to the fourth (with loading factor $=0,577$ ). Indicators of the smallest contribution is second indicator (with loading factor $=0,449$ ). The fourth indicator is fairness, that fairness and equality in the rights of meet stakeholders in private universities arising under the cooperation agreement and the legislation in force. The second indicator is accountability, which account for resource management and policy 
implementation is entrusted to the leadership of private universities in achieving the goals set periodically. In connection with that, the lecturer expects of leaders act fairly and not discriminate treatment to stakeholders. Faculty, staff and students should receive the same treatment. Although statistically, accountability have contributed the least, but in practice management, leaders in private universities must consider the question of accountability factor. This is supported the empirical research, governance is positive and significant effect on services quality (Jamal Karim, 2011).

Financial capability have a negative but insignificant effect on service quality effect of $-0,602$, (p-value $=0,288,>0$, 05). The dominant contribution is the fourth indicator (loading factor $=0,734$ ) and the smallest contribution is the fifth indicator (loading factor $=0,408$ ). The fourth indicator is: Audit, financial governance audited by internal auditors and external auditors. Medium fifth indicator is: Able to support the academic process, the inflow of funds allocated sufficient to run the learning process according the existing the Government accounting standards (SAP). So according to the lecturer, so that the private universities has a transparent financial administration and accountability, it is necessary in the private universities financial administration periodically audited, either by the internal auditor and the external auditor. From the research data obtained, only Indonesian Moslem University meeting that expectation. Correspondingly, a lecturer in private universities also hopes that the funds allocated to support the teaching and learning process sufficient quantity. Data showed that the allocation of funds in the private universities is generally inadequate. The fact that causes financial aspects of this has a negative impact on service quality in the private universities. This is supported by research Sebastian Andrew (2012) demonstrate the financial capability insignificant effect on service quality and performance.

Communication is positive and significant effect on lecturers performance at 0,279 (p-value $=0,044,<0.05)$. The dominant contribution of communication indicator is an indicator of the sixth with a loading factor 0,663 and the smallest contribution indicator is eighth (loading factor $=0,448$ ). The sixth indicator is the effect or outcomes, which are the level of understanding of students on teaching materials, are delivered lecturers on teaching and learning activities. Indicators eighth is Noise (interference), is everything that affects the lack of effective transfer of information (teaching materials) from faculty to students. This means, a lecturer in delivering course material particular emphasis on student understanding on lectures delivered. Private universities samples are generally less attention to aspects of interference (noise) that will affect student enrolment on the course material is delivered. Pressure on the result that triggered this communication has a positive and significant effect on lecturer's performance in private universities. This is supported by research Wulandari (2010) which showed the communication is positive and significant effect on lecturer's performance.

Governance has a positive but insignificant effect on lecturers performance of 0,009 ( $\mathrm{p}$-value $=0.935,>0,05$ ). Although not significant, but as a positive mathematical sign, then when the governance at private universities, particularly the teaching-learning process is increased, then the performance of lecturers in private universities will be triggered to increase. But if the governance of the learning process in the private universities does not well properly, then faculty performance will also decrease. This is supported by studies Jamal Karim (2011) demonstrated governance positive and significant impact on performance.

Financial capability has a positive and significant effect on lecturers performance at 0,356 (p-value $=0,048,<0$, 05). This means that the allocation of funds to support teaching and learning activities in private universities felt quite by teachers so positive and significant impact on performance. This is supported by studies Solomon Adams (2011), either directly or indirectly, financial capability positive and significant effect on performance.

The service quality is positive and significant effect on lecturers performance at 0,244 ( $p$-value $=0,032,<0,05$ ). Indicator of the service quality is the dominant contribution is the first indicator of the loading factor 0,709 and the smallest contribution is second indicator (loading factor $=0,342$ ). The first indicator is the physical evidence (tangible), useful to measure the study room facilities, learning and teaching facilities, library facilities and internet campus. The second indicator is empathy (empathy), aims to measure the degree of understanding of the leadership, faculty and staff to provide sincere and heartfelt. This means, a lecturer in assessing the services quality to be considered students especially the physical appearance of private universities, especially regarding the lecture hall, completeness means learning and teaching process (PBM), a library and internet campus. Average student or prospective student less expensive private universities problem general attitude of the staff in serving, empathize or not. This is supported by research Sumantri (2011) show the service quality is a positive and significant effect on lecturer's performance. 
Communication through service quality is positive and significant effect on lecturers performance of 0,203 (p-value $=0,044$ or $<0,05$ ). The coefficient value has a positive, then the indirect effect of the increase in total effect into 0 , 481. The net effect of this is the largest of the three exogenous variables. This is supported by research Wulandari (2010), which showed the communication is positive and significant on lecturer's performance: The mediating role of service quality.

Governance through service quality is positive and insignificant effect on lecturer performance at 0,173 and $p$-value $=0.935>0.05$. Because the coefficient has a positive mathematical sign, then the indirect effect of the increase in total effect into 0,183 . The net effect of this is the smallest of the three exogenous variables. This is supported by studies Jamal Karim (2011) demonstrated the governance is positive and significant effect on performance: the mediating role of service quality.

Financial capability through the services quality is negative and insignificant effect on lecturers performance of 0,147 with p-value $=0,048,<0,05$. The coefficient value has a negative mathematical sign, then the indirect effect of the total effect into 0, 210. This is supported by research Sebastian Andrew (2012) demonstrate the financial capability not significant effect on the service quality and performance.

Based on the above interpretation, to determine the relationship through intermediate variable or mediating variable in terms of quality of service (Y) which is insignificant if it is still capable of as a mediator in the relationship, then tested Sobel in order to know how much the role of mediating variables are mediating variables free to the dependent variable. More details are shown as follows:

Effect of communication on lecturer performance: The mediating role of service quality

\begin{tabular}{|c|c|c|c|c|}
\hline Input: & & Test statistic: & Std. Error: & p-value: \\
\hline a 0.682 & Sobel test: & 1.47969183 & 0.13504569 & 0.13895551 \\
\hline b 0.293 & Aroian test: & 1.40205295 & 0.14252386 & 0.16089944 \\
\hline$s_{\mathrm{a}} 0.335$ & Goodman test: & 1.5718442 & 0.12712838 & 0.11598669 \\
\hline$s_{b} 0.136$ & Reset all & & Calculate & \\
\hline
\end{tabular}

Above calculation of Sobel test scores of 1,480 $<1.98$ significance level $0,139>0.05$, proving the service quality was unable to discuss the effect of communication on lecturer performance: The mediating role of service quality

Effect of governance on lecturer performance: The mediating role of service quality

\begin{tabular}{|c|c|c|c|c|}
\hline Input: & & Test statistic: & Std. Error: & p-value: \\
\hline a 0.739 & Sobel test: & 1.62403186 & 0.13332682 & 0.10436901 \\
\hline b 0.293 & Aroian test: & 1.5533886 & 0.1393901 & 0.12033032 \\
\hline$s_{\mathrm{a}} 0.299$ & Goodman test: & 1.70528174 & 0.12697433 & 0.08814189 \\
\hline$s_{\mathrm{b}} 0.136$ & Reset all & & Calculate & \\
\hline
\end{tabular}

Above calculation of Sobel test scores of 1,624 < 1, 98 significance level of $0,104>0.05$, proving that the service quality is not able to mediates the effect of governance on lecturer performance. 
Effect of financial capability on lecturer performance: The mediating role of service quality

\begin{tabular}{|c|c|c|c|c|}
\hline Input: & & Test statistic: & Std. Error: & p-value: \\
\hline a -0.636 & Sobel test: & -0.95367022 & 0.19540088 & 0.3402506 \\
\hline b 0.293 & Aroian test: & -0.88045333 & 0.21165006 & 0.37861378 \\
\hline$s_{\mathrm{a}} 0.598$ & Goodman test: & -1.04883287 & 0.17767178 & 0.29425505 \\
\hline$s_{b} 0.136$ & Reset all & & Calculate & \\
\hline
\end{tabular}

Above calculation results Sobel test scores of $-0,954<1,98$ significance level of 0,340 $>0,05$, proving that the service quality is not able to mediate the effect of financial capability on lecturer performance

\section{Conclusions}

Based on the analysis of the results of research and discussion, summarized as follows; (1) direct communication positive and significant impact on the quality of service. The intensity of the relationship between communication and good faculty and students and between faculty and staff has been applied properly to improve the quality of service; (2) direct governance positive and significant impact on the quality of service. The management system at private universities have been well established in accordance with the vision and mission of the private universities, which give effect to the quality of service; (3) direct financial capability and no significant negative effect on the quality of service. Still there are private universities that have not been self-sufficient and regular in holding ability of funding / finance in an effort to improve service quality;

Direct effect of (4) communication has positive and significant effect on the performance of lecturers. Implementation of effective communication has been actualized by both the faculty and students give effect to increase the performance of lecturers; (5) direct governance and no significant positive effect on the performance of lecturers. Management of private universities management system which has been held in accordance with the vision and mission of the private universities, but has not resulted in increased performance of lecturers; (6) direct financial capability and significant positive effect on the performance of lecturers. Financial capabilities are applied on an ongoing basis to give effect to increase the performance of lecturers; (7) directly service quality positive and significant impact on the performance of lecturers. The services quality that provides superior service and support of lecturer's performance improvement; 8) indirectly through quality communication services and has significant positive effect on the performance of lecturers.

The realization of communication through superior service quality of private universities to give effect to the achievement of college lecturer in carrying out activities; (9) indirectly governance through service quality and no significant positive effect on the performance of lecturers has been found. Management of private universities management system which has been held in accordance with the vision and mission of the private universities, but through the implementation of quality of service has not resulted in increased performance of lecturers; and 10) indirectly through the financial capability of service quality and significant negative effect on the performance of lecturers. The ability of funding has not been applied on an ongoing basis at several private universities, but through the quality of services provided by private universities to students and faculty members to give effect to increase the performance of lecturers.

\section{References}

1. Charvert, Gerry. (2010). Human Resource Management. Published by McGraw Hill, New York.

2. DeVito, Joseph A. (2008). Interpersonal Communication. Publisher Kharisma, Jakarta.

3. Directorate General of Higher Education, Ministry of National Education, Indonesia. (2015) Three pillars of higher education activities (Tridharma)

4. Djokopranoto, Syahdana. (2009). Overview Organizational Performance in Perspective. Publisher Tarsito, Bandung. 
5. Ministry of National Education, Republic of Indonesia, (2003). Law Number 20 Year 2003, About National Education System, Jakarta: Depdiknas

6. Simmon. (2010). Human Resource Management. West Publishing Company, New York.

7. Sumantri. (2011). Human Resource Management. Publisher Binarupa, Jakarta.

8. Sumego. (2008). The Human Resource Management. Publisher Raja Grafindo Persada, Jakarta.

9. Werther, Marvin. (2010). Human Resource Management. Published by McGraw Hill, Ohio. 